\title{
Edukasi terhadap masyarakat terkait mitigasi Coronavirus Disease (COVID-19) di Kabupaten Karawang
}

\author{
Nico*, Wahyudin Wahyudin, Indah Laily Hilmi \\ Universitas Singaperbangsa Karawang \\ email: "niconainggolan133@gmail.com
}

Received November 27, 2020; Revised January 21, 2021; Accepted January 22, 2021

\begin{abstract}
Abstrak
Coronavirus (COVID-19) merupakan penyakit menular yang disebabkan oleh coronavirus versi baru yang ditemukan pada akhir 2019 lalu. Pandemi Corona Virus Disease 2019 (COVID-19) telah menimbulkan dampak luar biasa bagi kesehatan, keamanan, keselamatan, dan ketenangan seluruh lapisan masyarakat. Peningkatan kasus secara signifikan menyebabkan semakin luasnya wabah pandemi yang ada. Secara global sampai dengan 22 November 2020, kasus terkonfirmasi mencapai 55.624.562 kasus yang tersebar di 205 negara dengan 1.388.100 kematian. Akan tetapi, masih banyak terdapat disinformasi dan misinformasi di masyarakat yang berujung kepada ketidaktahuan masyarakat akan bahaya dan penolakan dalam megikuti rekomendasi pemerintah. Gejala utama. penyakit COVID-19 antara lain batuk, demam, dan sesak napas. Penyakit ini menyerang semua golongan, dewasa, lansia, maupun anak-anak. Pengabdian kepada masyarakat ini bertujuan untuk memberikan edukasi serta menilai gambaran pengetahuan masyarakat kabupaten karawang terhadap mitigasi COVID-19. Pengabdian ini menggunakan metode kualitatif dengan memanfaatkan pendekatan virtual etnografi yan dilakukan secara online. Pemberian pengetahuan yang spesifik, valid, dan tepat sasaran mampu meningkatkan perilaku dalam pencegahan masyarakat terhadap virus COVID-19.
\end{abstract}

Kata Kunci: Edukasi Masyarakat; Corona Virus Disease; Mitigasi COVID-19

\section{Abstract}

Coronavirus (COVID-19) is an infectious disease caused by a new version of the coronavirus that was discovered at the end of 2019. The 2019 Corona Virus Disease (COVID-19) pandemic has a tremendous impact on the health, safety, and peace of all levels of society. The increase in cases significantly increases the extent of the existing pandemic outbreak. Globally as of 22 November 2020, confirmed cases reached 55,624,562 well-known cases in 205 countries with 1,388,100 deaths. However, there is still a lot of disinformation and misinformation in a society which leads to public ignorance of the dangers and refusal to comply with government recommendations. The main symptom. COVID-19 includes coughing, fever, and shortness of breath. This disease attacks all groups, adults, the elderly, and children. This community service aims to provide education and assess the description of the Karawang regency community's knowledge of COVID-19 mitigation. This service uses qualitative methods by utilizing an online virtual ethnographic approach. Providing specific, valid, and right-on-target knowledge that can improve behavior in community prevention against the COVID-19 virus.

Keywords: Public Education; Corona Virus Disease; Mitigation COVID-19

\section{PENDAHALUAN}

Badan Kesehatan Dunia (WHO) secara resmi menyatakan virus Corona COVID-19 sebagai pandemi. Pandemi sendiri merupakan skala penyebaran penyakit yang terjadi secara global di seluruh dunia. Suatu wabah yang dikatakan sebagai pandemi artinya WHO memberi alarm pada pemerintah semua negara dunia untuk meningkatkan kesiapsiagaan untuk mencegah maupun menangani wabah. Pandemi Corona Virus Disease 2019 (COVID-19) telah menimbulkan dampak luar biasa bagi kesehatan, keamanan, keselamatan, dan ketenangan seluruh lapisan masyarakat. Dalam rangka pencegahan penyebaran COVID-19, Pemerintah telah menginstruksikan masyarakat untuk menghindari kerumunan (social distancing) dan menjaga kontak fisik (physical distancing) dalam melakukan aktivitas, seperti bekerja, beribadah dan kegiatan lainnya. Kasus pertama corona awalnya diidentifikasi sebagai flu pada tahun 1960 dengan sekitar 500 pasien diidentifikasi mengalami gangguan sistem pernapasan yang menyerupai flu [1]. Selanjutnya, corona diperlakukan sebagai virus yang tidak mematikan serta dianggap sederhana hingga tahun 2002. Pasca adanya Severe Acute Respiratory Syndrome (SARSCov) di China, para pakar mulai berfokus pada penyebab dan menemukan hasil apabila wabah ini diakibatkan oleh bentuk baru corona. Pada tahun 2012, terjadi wabah yang mirip yakni 
Middle East Respiratory Syndrome (MERS-Cov) di Timur Tengah. Dari kedua peristiwa tersebut diketahui bahwa corona bukan virus yang stabil, melainkan mampu berdaptasi menjadi lebih ganas, bahkan dapat mengakibatkan kematian [2].

Kajian lembaga Centers for Disease Control and Prevention menjelaskan bahwa penyebaran virus Corona kebanyakan terjadi antar manusia melalui cairan yang keluar saat batuk atau bersin. Karenanya, upaya preventif perlu dilakukan dengan menjaga jarak sekitar 1 sampai 2 meter [3]. Cairan yang mengandung virus Corona yang keluar melalui batuk atau bersin dapat menempel di bagian mulut atau hidung seseorang, kemudian terhirup saat mengambil napas dan masuk ke paru-paru. Potensi terinfeksi tiap orang sangat dipengaruhi tingkat imunitasnya. Seseorang rentan terinfeksi saat kondisi tubuh tidak sehat atau imunitas menurun. Lingkup penyebaran virus korona melalui tiga proses, yaitu local transmission, imported cases only, dan community spread. Proses penyebaran komunitas (community spread) menunjukkan kondisi yang cukup memprihatinkan, sebab seseorang bisa terinfeksi dengan tanpa sadar kapan dan dimana hal tersebut terjadi. Tanda dan gejala umum infeksi COVID-19 antara lain gejala gangguan pernapasan akut seperti batuk kering, demam $\geq 38^{\circ} \mathrm{C}$, dan sesak napas. Tanda-tanda dan gejala klinis yang dilaporkan pada sebagian besar kasus adalah demam, dengan beberapa kasus mengalami kesulitan bernapas, dan hasil rontgen menunjukkan infiltrat pneumonia luas di kedua paru [4].

Di Indonesia, sejak dua kasus pertama COVID-19 yang diumumkan pada 2 Maret 2020, jumlah kasusnya terus meningkat tersebar di 32 provinsi. Per-17 April 2020 terkonfirmasi terdapat 5.923 kasus, dengan korban meninggal sebanyak 502 orang dan pasien sembuh sebnyak 607 orang [5]. Berdasarkan data dari Gugus Tugas Percepatan Penanganan COVID-19 pesebaran COVID-19 di wilayah Jakarta menjadi peringkat pertama pasien terbanyak terkena virus Corona. Sedangkan provinsi terbanyak kedua terkena virus Corona yaitu Jawa Barat dan kemudian diikuti Jawa Timur, Banten dan Jawa Tengah. Jumlah pasien Covid 19 yang terus meningkat tanpa terkendali menjadikan Pemerintah memutuskan mengambil kebijakan Pembatasan Sosial Berskala Besar atau PSBB dalam menangani pandemi virus Corona atau COVID-19 di Tanah Air. Kebijakan tersebut diambil setelah pemerintah menilai penyakit ini merupakan penyakit yang dengan faktor risiko tinggi. Sebagai tindak lanjut atas kebijakan PSBB, maka beberapa arahan yang harus ditaati diantaranya seperti kegiatan sekolah dan bekerja dilakukan di rumah, pembatasan kegiatan keagamaan, pembatasan kegiatan di tempat atau fasilitas umum, pembatasan kegiatan sosial dan budaya, pembatasan moda trasportasi, pembatasan kegiatan aspek lainnya khusus terkait aspek pertahanan dan keamanan. Kondisi perang melawan COVID-19 yang dialami saat ini menuntut masyarakat harus beraktivitas di rumah, menjaga jarak dengan orang lain dan menghindari kerumunan. Semua aktivitas dan komunikasi dilakukan secara online, tanpa harus keluar rumah. Hal ini dilakukan agar kita segera dapat menahan laju penyebaran yang terinfeksi virus Corona (COVID-19). Selain itu, untuk pencegahan COVID-19 terkait dengan layanan khususnya pendidikan, Pemerintah telah menganjurkan kepada setiap sekolah dan perguruan tinggi untuk melakukan pembelajaran secara online sehingga tidak terjadi kerumuanan dalam proses belajar mengajar.

Akan tetapi, kebijakan PSBB belum mampu mengendalikan jumlah pesebaran kasus COVID-19. Hal ini terlihat dari jumlah kasus COVID-19 yang terus bertambah setiap harinya. Analisis sementara bahwa masyarakat Indonesia pada umumnya masih belum paham bahkan acuh terhadap dampak dari virus Corona. Disisi lain tentunya ada faktor ekonomi yang menjadikan masyarakat terpaksa tetap beraktifitas di luar rumah Meliahat situasi ini, percepatan penganan COVID-19 harus dilakukan secara menyeluruh dan melibatkan semua pihak termasuk perguruan tinggi. Peran perguruan tinggi bisa dijadikan sebagai ujung tobak dalam peranannya untuk mensosialisasikan penanganan COVID-19 kepada masyarakat [6].

Beradasarkan observasi awal yang dilakukan di salah satu desa yang ada di Kabupaten Karawang, yaitu Desa Kalangsari dimana masih terdapat masyarakat yang belum memahami serta mengetahui akan protokol kesehatan dalam pencegahan virus Covid-19 yang ada. Selain itu, minimnya akan informasi serta terbatasnya media informasi yang ada menjadi penyebab utama yang terjadi dalam masyarakat yang berada di desa tersebut. Adapun Program pengabdian kepada masyarakat yang dilaksanakan dengan tujuan mampu memberikan pemahaman kepada mitra pengabdian terkait mitigasi atau pencegahan virus Covid-19 dan juga mampu memberikan ide dan solusi mengenai pencegahan virus Covid-19 khusunya di desa Desa Kalangsari berdasarkan hasil observasi yang ada.

\section{METODE}

Metode pada pengabdian ini menggunakan analisis kualitatif dan analisis kuantitatif. Selain itu, adapun analisis meliputi SWOT serta rancangan cross-sectional. Populasi yang terdapat dalam pengabdian yang dilaksanakan merupakan masyarakat Desa Kalangsari yang berjumlah 100 orang yang didominasi oleh anak muda dan orang tua (lansia). Teknik pengambilan sampel menggunakan purposive sampling dimana partisipan yang bersedia ikut dalam pengabdian. Data studi yang ada dikumpulkan dari kuisioner online serta yang disebarkan melalui media sosial. Kuisioner yang ada memuat pertanyaan yang digunakan untuk memperoleh data atau informasi terkait pemahaman dan usaha dalam pencegahan Coronavirus Disease 2019 (COVID-19) 
[7]. Selain itu, teknik analisis data dalam penelitian ini dilakukan secara bertahap, mulai dari editing, coding, scoring dan tabulasi. Dalam penelitian ini menggunakan skala likert yang dikembangkan oleh Ransis Likert. Tujuan dari skala ini untuk mengetahui tingkat penilaian edukasi terhadap masyarakat dengan menentukan skor pada setiap pertanyaan atau indikator dalam peluang. Metode kualitatif dapat digunakan untuk mengungkap dan memahami sesuatu dibalik fenomena yang sedikitpun belum diketahui. Analisis ini didasarkan pada logika yang dapat memaksimalkan pada faktor-faktor meliputi; kekuatan (strength) dan peluang (opportunity). Namun secara bersamaan dapat meminimalkan kelemahan (weakness) dan ancaman (Threat), yang diharapkan mampu untuk menyeimbangkan antara kondisi internal yaitu: kekuatan dan kelemahan dengan kondisi ekternal yaitu peluang dan ancaman yang ada, kemudian diimplementasikan dalam matriks SWOT, untuk mendapatkan beberapa strategi terbaik.

Matriks SWOT merupakan cara sistematik untuk mengidentifikasi keempat faktor yang tercakup dalam analisis yang menggambarkan kecocokan paling baik diantaranya. Analisis ini didasarkan pada asumsi bahwa suatu strategi akan memaksimalkan kekuatan dan peluang, serta meminimalkan kelemahan dan ancaman [8]. Data yang didapat kemudian dianalisis secara deskripsi untuk memperoleh gambaran bagaimana pemahaman serta tanggapan masyrakat terhadap edukasi yang telah dilakukan. Selain itu, video edukasi yang ada diharapkan mampu menarik minat masyarakat agar memahami serta mematuhi protokol dalam pencegahan COVID-19.

\section{HASIL DAN PEMBAHASAN}

Analisis SWOT merupakan sebuah singkatan dari Strength (Kekuatan), Weakness (Kelemahan), Opportunity (Kesempatan atau Peluang) dan Threat (Ancaman). Pertama kali dikenalkan oleh Albert Humphrey seorang pimpinan proyek di Universitas Stanford. Secara umum, analisis SWOT ini didasarkan pada anggapan jika sebuah strategi yang efektif berasal dari faktor internal (kekuatan dan kelemahan) dan juga eksternal (kesempatan dan ancaman). Oleh karena itu, analisis ini menggabungkan ke-empat faktor dari internal dan eksternal. Berikut merupakan analisis SWOT dari Edukasi terhadap masyarakat terkait Mitigasi Pandemi Covid-19 di Kabupaten Karawang terlampir pada tabel dibawah ini.

Tabel 1. Analisis Strength (Kekuatan) Terhadap Mitigasi COVID-19

\begin{tabular}{cl}
\hline No & \multicolumn{1}{c}{ Strength (Kekuatan) } \\
\hline 1 & Membuat prosedur yang dirancang untuk memberi pelayanan Terhadap COVID-19 \\
2 & $\begin{array}{l}\text { Sosialisasi (edukasi) terhadap masyarakat mengenai program penanggulangan COVID- } \\
19\end{array}$ \\
& \\
No & Strength (Kekuatan) \\
3 & Pemanfaatan Teknologi Informasi dalam Pemberian Edukasi terhadap masyarakat \\
4 & Melakukan Upaya Kerjasama (koordinasi) dengan berbagai pihak
\end{tabular}

Pada Tabel 1. menjelaskan faktor apa saja yang menjadi Strength (Kekuatan) dalam melaksanakan edukasi terhadap masyarakat. Dimana beberapa faktor yang ada memberikan dampak positif terkhusus bagi masyarakat yang belum memahami apa saja bahaya dari virus Covid-19 yang ada.

Tabel 2. Analisis Weakness (Kelemahan) Terhadap Mitigasi COVID-19

\begin{tabular}{cl}
\hline No & \multicolumn{1}{c}{ Weakness (Kelemahan) } \\
\hline 1 & Kurangnya Pemahaman masyarakat akan Teknologi Informasi yang ada \\
2 & Terbatasnya Penyediaan Fasilitas Fisik (Kelengkapan Sarana dan Prasarana) \\
3 & Kurangnya Komunikasi dan Koordinasi \\
4 & Belum Terbangunnya Budaya akan pentingnya mitigasi terhadap COVID-19 \\
\hline
\end{tabular}

Pada Tabel 2. menjelaskan faktor apa saja yang menjadi Weakness (Kelemahan) dalam melaksanakan edukasi terhadap masyarakat. Dimana beberapa faktor yang ada memberikan pertimbangan terutama saat melakuan edukasi yang ada bagi masyarakat yang belum memahami apa saja bahaya dari virus Covid-19 yang ada.

Tabel 3. Analisis Opportunities (Peluang) Terhadap Mitigasi COVID-19

\begin{tabular}{|c|c|}
\hline No & Opportunities (Peluang) \\
\hline 1 & Memiliki Anggota Tim Kerja dalam melakukan sosialisasi akan Pandemi COVID-19 \\
\hline 2 & $\begin{array}{l}\text { Meningkatkan koordinasi pelaksanaan penanggulangan dan pencegahan COVID-19 } \\
\text { (Teamwork) }\end{array}$ \\
\hline 3 & Mampu dalam memenuhi harapan masyarakat (Key Performance Indicator) \\
\hline
\end{tabular}


4 Pengoptimalan Penguasaan Teknologi dalam sosialisasi terhadap masyarakat

Pada Tabel 3. menjelaskan faktor apa saja yang menjadi Opportunities (Peluang) dalam melaksanakan edukasi terhadap masyarakat. Adapun tujuan dari dilakukan edukasi yang ada dengan harapan dapat memahami serta menaati terutama protokol Covid-19 yang ada sesuai dengan ketentuan dari pemerintah. Pada Tabel 4. Dibawah ini terdapat beberapa faktor yang menjadi Threat (Ancaman) Terhadap Mitigasi COVID-19 yang ada.

Tabel 4. Analisis Threat (Ancaman) Terhadap Mitigasi COVID-19

\begin{tabular}{cl}
\hline No & \multicolumn{1}{c}{ Threat (Ancaman) } \\
\hline 1 & Sosialisasi yang tidak merata terhadap seluruh masyarakat \\
2 & Kurangnya Anggaran (Anggaran terbatas) \\
3 & Fasilitas Fisik yang tersedia masih terbatas (Kurang memadai) \\
4 & Lingkungan sosial yang mengalami perubahan (Pro dan Kontra terhadap program yang \\
& ada) \\
\hline
\end{tabular}

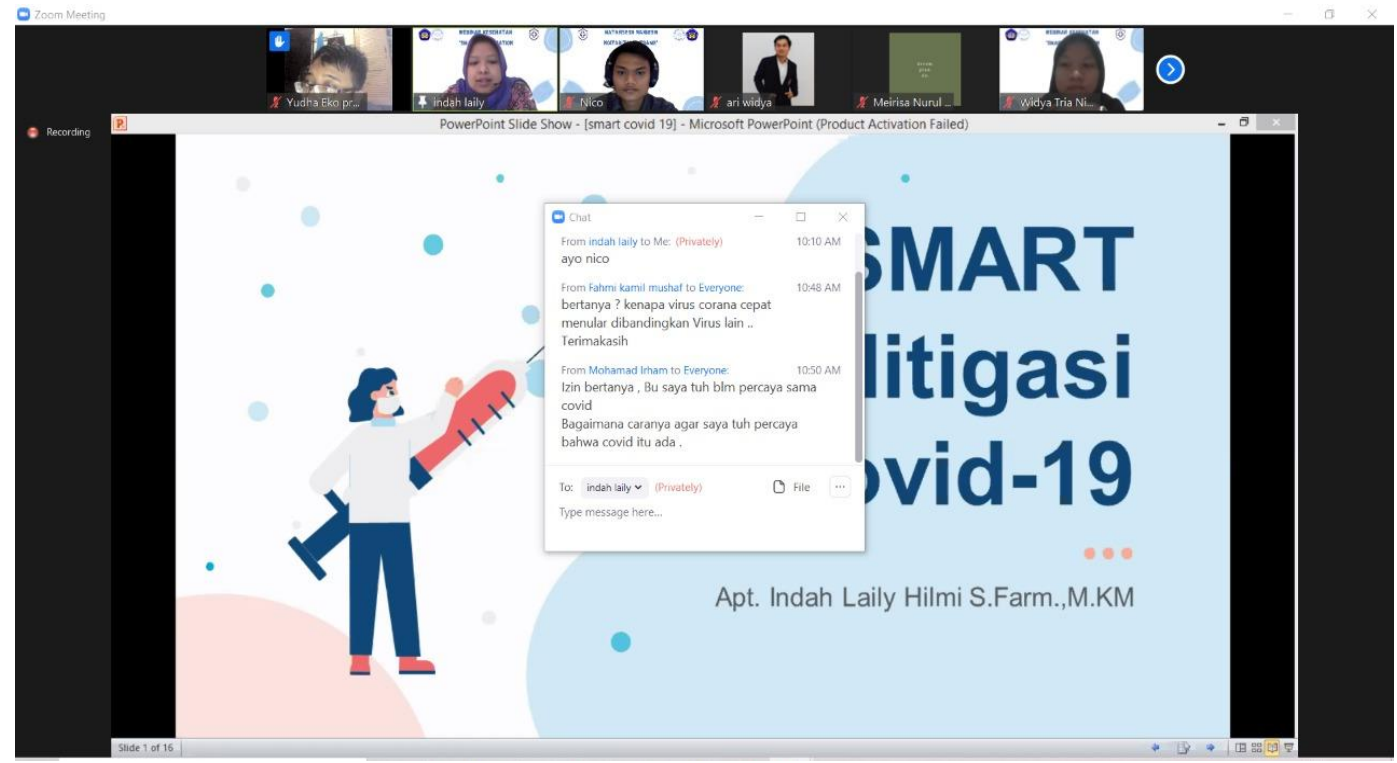

Gambar 1. Edukasi Masyarakat Terkait Mitigasi COVID-19

Gambar 1. merupakan edukasi yang dilakukan secara online dimana sosialisasi yang dilakukan berupa pemaparan serta video edukasi terhadap masyarakat terkhusus disaat tingkat kasus pandemi yang semakin meningkat secara signifikan setiap harinnya [9]. Hal ini tentunya sangat bermanfaat bagi masyarakat, serta menumbuhkan kesadaran masyarakat, terutama dalam mematuhi serta menaati akan protokol yang ada. Video edukasi yang ada juga mengajarkan masyarakat agar selalu menjaga serta mematuhi 3M, yaitu memakai masker, mencuci tangan serta menjaga jarak saat berada di tempat umum. Selain itu, terdapat sesi tanya jawab dimana semakin menguatkan akan pemahaman masyarakat terhadap mitigasi Covid-19 [10]. Berdasarkan video edukasi yang ada, Adapun analisa SWOT yang ada ditinjau lebih lanjut dengan analisa sebagai berikut.

Tabel 5. Analisis SWOT (Faktor Internal atau IFE) Terhadap Video Edukasi Mitigasi COVID-19

\begin{tabular}{|c|c|c|c|c|}
\hline No & Strength & Weight & Rating & $\begin{array}{c}\text { Weighted } \\
\text { Score }\end{array}$ \\
\hline 1 & $\begin{array}{l}\text { Prosedur dirancang } \text { untuk memberi } \\
\text { pelayanan Terhadap Covid } 19 \text { yang } \\
\text { berkualitas }\end{array}$ & 0.10 & 4 & 0.40 \\
\hline No & Strength & Weight & Rating & $\begin{array}{c}\text { Weighted } \\
\text { Score }\end{array}$ \\
\hline 2 & $\begin{array}{l}\text { Sosialisasi } \begin{array}{c}\text { terhadap masyarakat } \\
\text { mengenai } \\
\text { covid } 19\end{array} \text { program penanggulangan } \\
\text {. }\end{array}$ & 0.08 & 3 & 0.24 \\
\hline 3 & Pemanfaatan & 0.07 & 4 & 0.28 \\
\hline
\end{tabular}




\begin{tabular}{|c|c|c|c|c|}
\hline \multirow[b]{2}{*}{4} & $\begin{array}{l}\text { dalam Pemberian Edukasi terhadap } \\
\text { masyarakat }\end{array}$ & & & \\
\hline & $\begin{array}{l}\text { Upaya Kerjasama dengan berbagai } \\
\text { pihak }\end{array}$ & 0.02 & 3 & 0.06 \\
\hline No & Weaknesses & Weight & Rating & $\begin{array}{l}\text { Weighted } \\
\text { Score }\end{array}$ \\
\hline 1 & $\begin{array}{l}\text { Kurangnya Pemahaman masyarakat } \\
\text { akan Teknologi Informasi }\end{array}$ & 0.10 & 2 & 0.20 \\
\hline 2 & $\begin{array}{l}\text { Terbatasnya Penyediaan Fasilitas Fisik } \\
\text { (Kelengkapan Sarana dan Prasarana) }\end{array}$ & 0.13 & 3 & 0.39 \\
\hline 3 & $\begin{array}{l}\text { Kurangnya } \\
\text { Koordinasi }\end{array}$ & 0.07 & 3 & 0.21 \\
\hline 4 & $\begin{array}{l}\text { Belum Terbangunnya Budaya akan } \\
\text { pentingnya mitigasi terhadap covid } 19\end{array}$ & 0.09 & 3 & 0.27 \\
\hline
\end{tabular}

Tabel 6. Analisis SWOT (Faktor Eksternal atau EFE) Terhadap Edukasi Mitigasi COVID-19

\begin{tabular}{llccc}
\hline No & \multicolumn{1}{c}{ Opportunities } & Weight & Rating & $\begin{array}{c}\text { Weighted } \\
\text { Score }\end{array}$ \\
\hline 1 & $\begin{array}{l}\text { Memiliki Anggota Tim Kerja dalam } \\
\text { sosialisasi }\end{array}$ & 0.02 & 3 & 0.06 \\
2 & $\begin{array}{l}\text { Meningkatkan koordinasi pelaksanaan } \\
\text { penanggulangan dan pencegahan covid } \\
19\end{array}$ & 0.17 & 5 & 0.85 \\
3 & $\begin{array}{l}\text { Mampu dalam memenuhi harapan } \\
\text { masyarakat }\end{array}$ & 0.05 & 5 & 0.25 \\
4 & $\begin{array}{l}\text { Pengoptimalan Penguasaan Teknologi } \\
\text { dalam sosialisasi terhadap masyarakat }\end{array}$ & 0.12 & 4 & 0.48 \\
No Threats & Weight & Rating & Weighted \\
& $\quad 0.06$ & 2 & 0.12 \\
1 & $\begin{array}{l}\text { Sosialisasi yang tidak merata } \\
\text { Kurangnya Anggaran }\end{array}$ & 0.04 & 4 & 0.16 \\
3 & $\begin{array}{l}\text { Fasilitas Fisik terbatas (Kurang } \\
\text { memadai) }\end{array}$ & 0.02 & 2 & 0.04 \\
4 & $\begin{array}{l}\text { Lingkungan sosial yang mengalami } \\
\text { perubahan }\end{array}$ & 0.08 & 3 & 0.24 \\
\hline
\end{tabular}

Setelah dilakukannya perhitungan analisis SWOT, maka didapatkan matriks antara nilai faktor internal dan faktor eksternal sebagai berikut. 


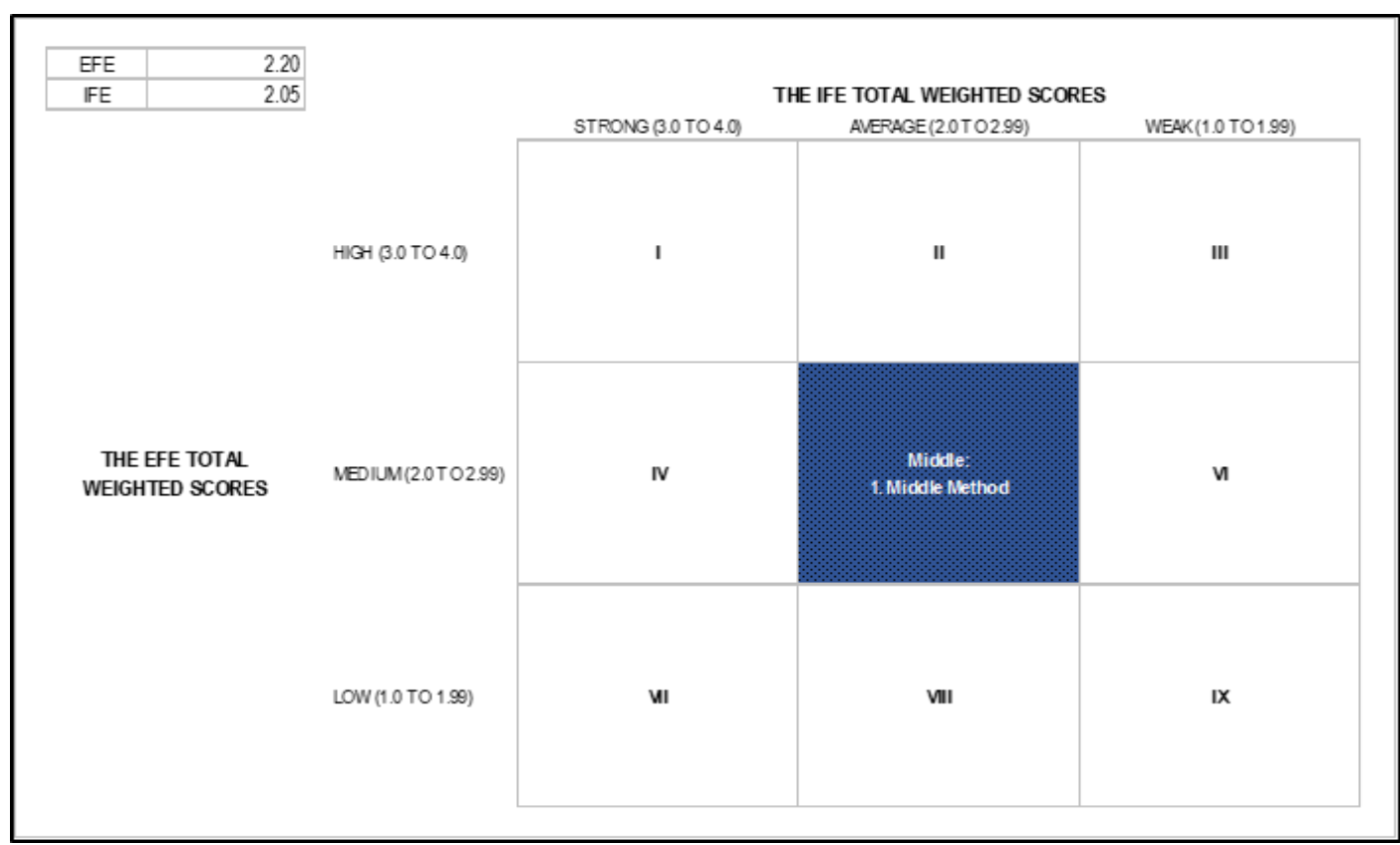

Gambar 2. Matrix nilai dari IFE dan EFE Terhadap Edukasi Mitigasi COVID-19

Kegiatan ini dilakukan secara online (daring) karena tidak memungkin melakukan pertemuan saat Pemerintah melakuan PSBB untuk memutus penyebaran mata rantai virus Corona. Pandemik COVID-19 juga menyebabkan edukasi yang ada dilakukan secara online dan jarak jauh. Video Edukasi Mitigasi COVID-19 juga mendapat respon yang yang baik dari masyarakat khususnya Desa Kalangsari. Mayarakat dapat memanfaatkan video Edukasi Mitigasi COVID-19 sebagai pedoman dalam pencegahan virus COVID-19 sesuai protokol kesehatan anjuran Pemerintah [11]. Hasil respon masyarakat terhadap video Edukasi Mitigasi COVID-19 dilakukan melalui survei kepada masyarakat yang berada di Kabupaten Karawang, tepatnya di Desa Kalangsari. Jumlah masyarakat yang mengisi kuesioner sejumlah 100 orang yang dikirimkan melalui media sosial berupa google form pada tanggal 8 November 2020 yang dilakukan dengan secara online (daring). Hasil survei tersebut adalah sebagai berikut.

Tabel 7. Respon Masyrakat Terhadap Video Edukasi Mitigasi COVID-19

\begin{tabular}{|c|c|c|c|c|c|}
\hline \multirow{3}{*}{ No } & \multirow{3}{*}{ Video } & \multicolumn{4}{|c|}{ Pernyataan dan Respon } \\
\hline & & \multicolumn{2}{|c|}{$\begin{array}{l}\text { Video yang disampaikan } \\
\text { bermanfaat }\end{array}$} & \multicolumn{2}{|c|}{$\begin{array}{c}\text { Video yang disampaikan } \\
\text { menarik }\end{array}$} \\
\hline & & $\mathrm{Ya}$ & Tidak & $\mathrm{Ya}$ & Tidak \\
\hline \multirow[t]{2}{*}{1} & $\begin{array}{lll}\text { Video } & \text { Pandangan } & \text { Mitigasi }\end{array}$ & 89 & 11 & 84 & 16 \\
\hline & COVID-19 & $89 \%$ & $11 \%$ & $84 \%$ & $16 \%$ \\
\hline \multirow[t]{3}{*}{2} & Pembuatan alat Hand sanitizer & 76 & 24 & 71 & 29 \\
\hline & sistem injak (tanpa disentuh) & $76 \%$ & $24 \%$ & $71 \%$ & $29 \%$ \\
\hline & \multirow{3}{*}{ Video } & \multicolumn{4}{|c|}{ Pernyataan dan Respon } \\
\hline \multirow[t]{2}{*}{ No } & & \multicolumn{2}{|c|}{$\begin{array}{c}\text { Video yang disampaikan } \\
\text { bermanfaat }\end{array}$} & \multicolumn{2}{|c|}{$\begin{array}{c}\text { Video yang disampaikan } \\
\text { menarik }\end{array}$} \\
\hline & & Ya & Tidak & $\mathrm{Ya}$ & Tidak \\
\hline \multirow[t]{2}{*}{3} & Langkah-Langkah yang dapat & 91 & 9 & 87 & 13 \\
\hline & $\begin{array}{l}\text { diterapkan dalam pencegahan } \\
\text { COVID-19 }\end{array}$ & $91 \%$ & $9 \%$ & $87 \%$ & $13 \%$ \\
\hline
\end{tabular}

Berdasarkan respon dari 100 responden, video Edukasi Mitigasi COVID-19 yang telah dibuat mendapatkan respons yang baik. Video pertama dimana berisi pengetahuan tentang definisi dan karakteristik Mitigasi COVID-19 yang sifatnya deskriptif dimana terdapat muatan praktik yang dapat diaplikasikan. Pada dua pernyataan lainnya, seperti video menarik dan video bermanfaat tetap ditanyakan kepada audiens. Pada pernyataan di tema pertama ini, dominannya audiens mengatakan atau merespon "Ya", dimana terbukti terdapat $89 \%$ masyarakat mengatakan bahwa video Pandangan Mitigasi COVID-19 bermanfaat dan 84\% mengatakan bahwa video mengenai Pandangan Mitigasi COVID-19 menarik. Selanjutnya untuk tema video 
yaitu Pembuatan alat Hand sanitizer sistem injak (tanpa disentuh), juga mendapatkan respon yang positif terbukti dari $76 \%$ masyarakat menyatakan bahwa video bermanfaat, sebanyak $71 \%$ menyatakan bahwa video menarik. Respon yang sama juga terdapat dalam video 3 yaitu Langkah-Langkah yang dapat diterapkan dalam pencegahan COVID-19, dimana 91\% masyarakat menyatakan video yang disampaikan bermanfaat, 99,2\% masyarakat menyatakan bahwa video yang disampaikan bermanfaat, dan $87 \%$ menyatakan jika video menarik dalam penyampaiannya. Sehingga, dari video edukasi yang ada, selain dapat mensosialisasi agar warga lebih memahami lagi bagaimana cara menghadapi COVID-19, video edukasi juga mampu berperan serta dalam mengajarkan masyarakat agar selalu berhati-hati serta menganstisipasi pandemic COVID-19 dengan menerapkan pola hidup sehat dalam kehidupan sehari-hari.

\section{KESIMPULAN}

Dalam rangka pencegahan penyebaran Covid-19, Pemerintah telah menginstruksikan masyarakat untuk menghindari kerumunan (social distancing) dan menjaga kontak fisik (physical distancing) dalam melakukan aktivitas. Selain itu, media edukasi berbasis video dapat membantu masyarakat dalam meningkatkan pemahaman, terpercaya, memudahkan penafsiran, serta memperoleh informasi tentang Edukasi Mitigasi COVID-19. Adapun penerapan SWOT yang ada dapat meningkatkan akan edukasi yang ada, khususnya bagi masyarakat yang ada. Masyarakat juga dapat memahami dan mengetahui langkah-langkah dalam mitigasi atau pencegahan Virus COVID-19, mematuhi protokol yang ada dalam pencegahan Virus COVID-19 serta menerapkan pola hidup sehat dalam kehidupan sehari-hari.

\section{DAFTAR PUSTAKA}

[1] Gunawan Wiradharma, "Video Panduan Pembelajaran Online untuk Mahasiswa Tingkat Awal," J. Din., vol. 4 No. 3, pp. 391-392, 2020.

[2] Bakornas Penanggulangan Bencana, Pengenalan Karakteristik Bencana dan Upaya Mitigasinya di Indonesia. Jakarta: Direktorat Mitigasi Lahar BAKORNAS PB, 2013.

[3] Tim Kerja Kementerian Dalam Negeri, "Pedoman Umum Menghadapi Pandemi Covid-19 Bagi Pemerintah Daerah : Pencegahan, Pengendalian, Diagnosis dan Manajemen," J. Chem. Inf. Model., vol. 53, no. 9, pp. 16891699, 2013, doi: 10.1017/CBO9781107415324.004.

[4] M. M. C. Otálora, "Yuliana," Parq. los afectos. Jóvenes que cuentan, vol. 2, no. February, pp. 124-137, 2020, doi: 10.2307/j.ctvzxxb18.12.

[5] Satgas Covid-19 Karawang, "Dashboard Kasus Covid-19 Kabupaten Karawang," 2020. http://covid.19.karawangkab.go.id/data/.

[6] V. Kristina, "Kiprah Mahasiswa UNDIP Melakukan KKN di tengah Pandemi,"www.kompas.com,2020.https://muda.kompas.id/baca/2020/08/24/kiprah-mahasiswa-undip-melakukankkn-di-tengah-pandemi/.

[7] A. Sadiman, A. S., Rahardjo, R., \& Haryono, Media pendidikan pengertian, pengembagan, dan pemanfaatan. Jakarta, 2014.

[8] I. Emaliana, "Pelatihan Penulisan Karya Ilmiah Bagi Guru MGMP Bahasa Inggris SMA/MA Se-Malang Raya," $J$. Pengabdi. Kpd. Masy., vol. 3, pp. 273-279, 2019.

[9] U. Erniasih and S. E. Pramono, "Perbedaan Hasil Belajar Dengan Menggunakan Media Video Edukasi Dan Media Video Dokumenter Pada Pembelajaran Sejarah Di Sma N 12 Semarang Tahun Ajarah 2017/2018," Indones. J. Hist. Educ., vol. 6, no. 2, pp. 162-171, 2018.

[10] L. Agustino, "Analisis Kebijakan Penanganan Wabah Covid-19: Pengalaman Indonesia Analysis Of Covid-19 Outbreak Handling Policy: The Experience Of Indonesia," Junal Borneo Adm., vol. 16, no. 2, pp. 253-270, 2020.

[11] D. Daud, "Social Distancing dan Budaya Kita," Pandemik COVID-19 Persoalan dan Refleks., no. May, pp. 3947, 2020, [Online]. Available: https://www.researchgate.net/publication/341218892. 
